Brit. F. vener. Dis. (1970) 46, 386

\title{
Fluorescent treponemal antibody-absorption (FTA-ABS) test in patients with aortic valvular insufficiency ${ }^{1,2}$
}

\author{
B. R. BAUMGARTNER, ${ }^{3}$ N. K. WENGER, ${ }^{3}$ M. A. LANTZ, AND L. C. NORINS \\ Venereal Disease Research Laboratory, Venereal Disease Branch, State and Community Services Division, \\ National Communicable Disease Center, Health Services and Mental Health Administration, \\ Public Health Service, U.S. Department of Health, Education, and Welfare, Atlanta, Georgia 30333, U.S.A.
}

Aortic valvular insufficiency caused by syphilis cannot be differentiated by murmur or other clinical characteristics from other causes of aortic insufficiency, and the aid of serological tests is often sought. Routine serological tests for syphilis, such as the VDRL slide test, which utilize cardiolipin antigens, are reactive in only 75 to 95 per cent. of patients with cardiovascular syphilis diagnosed clinically (Cole, 1937; Kampmeier, 1964; Olansky, 1967; Rosahn, 1955; Slatkin, 1965). The fluorescent treponemal antibodyabsorption (FTA-ABS) test (Hunter, Norins, Falcone, and Stout, 1968), using Treponema pallidum organisms as the antigen, provides greater sensitivity in the sero-diagnosis of latent and tertiary syphilis: it is reactive in more than 95 per cent. of cases (Deacon, Lucas, and Price, 1966; Atwood, Millar, Stout, and Norins, 1968). In the present retrospective study, we describe the reactivity and diagnostic value of the FTA-ABS and VDRL slide tests in patients with the clinical diagnosis of aortic valvular insufficiency.

\section{Material and methods}

PATIENT GROUP

The Grady Memorial Hospital and Cardiac Clinic records of 159 patients with the clinical diagnosis of aortic valvular insufficiency were reviewed. Each patient was categorized according to the conclusion in the record (which was based on history and serological tests) regarding the presumed aetiology of the aortic insufficiency: luetic, rheumatic, miscellaneous, or unknown. The penultimate category includes hypertensive and congenital aortic insufficiency, and aortic insufficiency secondary to bacterial endocarditis, aortic dissection, fenestration of an aortic cusp, or Marfan's syndrome. For this study, it was not feasible to reinterview each patient regarding a history of syphilitic

Received for publication February 17, 1970.

1Trade names are used for identification only and do not represent an endorsement by the Public Health Service or the U.S. Department of Health, Education, and Welfare.

'Supported, in part, by a grant (5T01-HE05380) from the United States Public Health Service, Department of Health, Education, and Welfare, Washington, D.C.

${ }^{3}$ From the Department of Medicine, Emory University School of Medicine, and the Cardiac Clinics, Grady Memorial Hospital, Atlanta, Georgia.

Reprint requests to Dr L. C. Norins. infection. Therefore, evidence of previous syphilis was obtained from review of the hospital records; e.g. a history of a lesion resembling primary or secondary syphilis, or a previous diagnosis of latent syphilis made largely on a reactive nontreponemal test. We recognized that the absence of this information in the record did not exclude the possibility of syphilitic infection in the past, and that the presence of scanty evidence did not rigorously establish that there had been a past infection. All 159 patients had previously been tested with a nontreponemal test, usually the VDRL slide, and many had also had an FTA-ABS test (performed by the Georgia State Department of Public Health). For this study, serum was again obtained from each patient. The Venereal Disease Research Laboratory, National Communicable Disease Center, performed VDRL slide and FTA-ABS tests on all blood specimens according to standard techniques (U.S. Department of Health, Education, and Welfare, 1969) before receipt of clinical information.

\section{Results}

The results are summarized in Tables I and II (opposite).

On the sera obtained currently, 58 of the 159 patients (36 per cent.) had a reactive FTA-ABS test and 33 (21 per cent.) had a reactive VDRL slide test. Of the 58 patients with a reactive FTA-ABS test, 42 (72 per cent.) had a history of syphilis and 39 (67 per cent.) a history of previous therapy for syphiliseither bismuth or arsenicals, or both.

Of the 33 patients with a clinical diagnosis of luetic aortic insufficiency, 31 (94 per cent.) had a reactive FTA-ABS test ; 27 ( 82 per cent.) had a history of syphilis; and 19 (58 per cent.) had a reactive VDRL slide test. Two patients with a clinical diagnosis of luetic aortic insufficiency, but with no record of primary or secondary syphilis, had nonreactive VDRL slide and FTA-ABS tests. One of these diagnoses had apparently been made solely on the basis of $x$-ray calcification of the ascending aorta. The other diagnosis was based on a single reactive Kahn test in 1947. After the reactive test was found, bismuth and arsenical therapy was given. Nontreponemal tests have since always been non- 
TABLE I Historical and laboratory data on 159 patients with aortic valvular insufficiency

\begin{tabular}{|c|c|c|c|c|c|c|c|c|c|c|c|c|c|}
\hline \multirow{3}{*}{$\begin{array}{l}\text { Aetiological } \\
\text { categorization in } \\
\text { hospital record }\end{array}$} & \multirow{3}{*}{$\begin{array}{l}\text { No. of } \\
\text { patients }\end{array}$} & \multirow{2}{*}{\multicolumn{2}{|c|}{$\begin{array}{l}\text { History of } \\
\text { syphilis }\end{array}$}} & \multirow{2}{*}{\multicolumn{2}{|c|}{$\begin{array}{l}\text { History of acute } \\
\text { rheumatic fever }\end{array}$}} & \multicolumn{4}{|c|}{$V D R L$ slide test reactive } & \multicolumn{4}{|c|}{$F T A-A B S$ test reactive } \\
\hline & & & & & & \multicolumn{2}{|c|}{ Previously } & \multicolumn{2}{|c|}{ Currently } & \multicolumn{2}{|c|}{ Previously } & \multicolumn{2}{|c|}{ Currently } \\
\hline & & No. & Per cent. & No. & Per cent. & No. & Per cent. & No. & Per cent. & No. & Per cent. & No. & Per cent. \\
\hline $\begin{array}{l}\text { Luetic } \\
\text { Rheumatic } \\
\text { Miscellaneous } \\
\text { Unknown }\end{array}$ & $\begin{array}{l}33 \\
69 \\
18 \\
39\end{array}$ & $\begin{array}{r}27 \\
8 \\
3 \\
7\end{array}$ & $\begin{array}{l}82 \\
12 \\
17 \\
18\end{array}$ & $\begin{array}{r}0 \\
52 \\
0 \\
0\end{array}$ & $\begin{array}{r}0 \\
75 \\
0 \\
0\end{array}$ & $\begin{array}{r}22 \\
6 \\
2 \\
8\end{array}$ & $\begin{array}{r}67 \\
9 \\
11 \\
21\end{array}$ & $\begin{array}{r}19 \\
5 \\
3 \\
6\end{array}$ & $\begin{array}{r}58 \\
7 \\
17 \\
15\end{array}$ & $\begin{array}{c}23 / 26 \\
10 / 53 \\
2 / 9 \\
8 / 32\end{array}$ & $\begin{array}{l}88 \\
19 \\
22 \\
25\end{array}$ & $\begin{array}{r}31 \\
11 \\
4 \\
12\end{array}$ & $\begin{array}{l}94 \\
16 \\
22 \\
31\end{array}$ \\
\hline Total & 159 & 45 & 28 & 52 & 33 & 38 & 24 & 33 & 21 & 43 & 27 & 58 & 36 \\
\hline
\end{tabular}

TABLE II Comparison of serological test results with clinical categorization or aortic valvular insufficiency

Serological tests

Relation of VDRL slide and FTA-ABS test results to diagnostic category of aortic valvular insufficiency as recorded in hospital record

VDRL slide + and FTA-ABS +

VDRL slide - and FTA-ABS +

VDRL slide + and FTA-ABS -

VDRL slide - and FTA-ABS -

VDRL slide + and FTA-ABS borderline

VDRL slide - and FTA-ABS borderline

\begin{tabular}{lllll}
\hline Luetic & Rheumatic & Miscellaneous & Unknown \\
\cline { 3 - 5 } 19 & 5 & 3 & 5 \\
12 & 6 & 1 & 7 \\
0 & 0 & 0 & 0 \\
2 & 55 & 13 & 25 \\
0 & 0 & 0 & 1 \\
0 & 3 & 1 & 1 \\
\hline
\end{tabular}

reactive. In retrospect, these patients probably did not have aortic insufficiency of luetic aetiology.

There were 69 patients who were considered to have rheumatic aortic insufficiency. Eleven (16 per cent.) of these had a reactive FTA-ABS test; seven of them had a history of syphilis and previous treatment, and five had a reactive VDRL slide test. Two patients diagnosed as having rheumatic aortic insufficiency had reactive FTA-ABS tests and no history of acute rheumatic fever. Rheumatic aortic insufficiency was diagnosed in these patients by the associated mitral valvular involvement.

Of the eighteen patients thought to have aortic insufficiency of miscellaneous cause, four (22 per cent.) had a reactive FTA-ABS test. Three of these had a history of treated syphilis and a reactive VDRL slide test, but another documented cause for aortic insufficiency : acute bacterial endocarditis, fenestration of an aortic cusp confirmed at surgery, and systemic hypertension in the range of $210 / 130 \mathrm{~mm}$. Hg. Thus, the reactive FTA-ABS test and a history of syphilis did not in themselves establish the aetiology of the aortic insufficiency.

Of the 39 patients clinically diagnosed as having aortic insufficiency of unknown aetiology, twelve ( 31 per cent.) had a reactive FTA-ABS test, seven (18 per cent.) a history of syphilis, and six (15 per cent.) a reactive VDRL slide test. This additional historical and serological information suggests that syphilis deserves additional consideration in this group of patients.

\section{Discussion}

This is the first study of FTA-ABS reactivity in a series of patients with aortic valvular insufficiency. It is known that, in late syphilis, the FTA-ABS test is more sensitive than the VDRL slide test (Deacon and others, 1966; Atwood and others, 1968). Thus we were not surprised to find that the FTA-ABS test was reactive in 94 per cent. of the patients clinically diagnosed as having luetic aortic insufficiency, whereas the VDRL slide test was reactive in only 58 per cent. Our study supports the concept that a nonreactive VDRL slide test does not rule out the possibility of syphilis. Other workers have reported that the VDRL slide test was reactive in 56 per cent. of patients with aortic valvular insufficiency, and that in 15 per cent. the Treponema pallidum immobilization (TPI) test was reactive even though the VDRL slide was non-reactive (Bleich, Lewis, and Marcus, 1966). As presently performed, neither the FTA-ABS nor the TPI test differentiates between treated and untreated syphilis, and both tests may remain reactive many years after presumably adequate treatment has been administered at the late stages (Atwood and others, 1968). On the other hand, the greater sensitivity of these treponemal tests may uncover some patients who have received only inadequate therapy, or who have been re-infected since their original treatment.

A reactive FTA-ABS test does not preclude the possibility that the patient may have another disease in addition to syphilis. In our series of aortic in- 
sufficiency patients, 27 of 58 FTA-ABS test reactors were thought to have aoric insuffiriency on a basis other than syphilis. Thus, a reactive $\mathrm{F}$. A-ABS test in itself indicates only the likelihood of present or past syphilis; it does not establish that syphilis has caused the aortic insufficiency. Even though the aetiology of aortic insufficiency has importance in management of the patient, especially as regards surgery, no definite aetiology may be established until studies are performed on tissue obtained at surgery or at autopsy. An exact answer may not be possible even then. It is hoped that, in the coming years, the relevant anatomical material can be reviewed as it becomes available.

Faced with clinical findings that, alone, do not clearly specify an aetiology, the physician may place great emphasis on a reactive serological test for syphilis. In reviewing the records of patients in our series, we found several instances in which the diagnostic balance seemed to have been tipped solely on the basis of a history of venereal disease or of a single reactive routine serological test for syphilis. Yet in the socioeconomic group from which most of our patients are derived, venereal disease is not uncommon. Cohen, Stout, and Ende (1969) found that about 17 per cent. of the unselected patients coming to the Grady Memorial Hospital had reactive FTAABS tests. Of the patients we studied, only 72 per cent. with reactive FTA-ABS tests had other evidence of a previous infection with syphilis. This does not mean that the other 28 per cent. did not have syphilis, but only that we could not elicit this history from the patient's clinical record. One wonders whether a history of syphilis had been vigorously sought from those patients in whom the cardiolipin antigen tests were non-reactive at the time of the initial examination.

Five cases of aortic insufficiency in our series seem to have been diagnosed as non-syphilitic on the basis of a single non-reactive (four) or borderline (one) FTA-ABS test in the past. But when tested for this study, all five patients had reactive FTA-ABS tests. When still another serum specimen was obtained and tested, one serum was reactive and four were borderline. According to recommendations (U.S. Department of Health, Education, and Welfare, 1969), 'borderline' results should not be considered as either reactive or non-reactive. If borderline results are obtained on a repeat specimen, the diagnosis will have to be resolved on other than a serological basis. If the FTA-ABS test result is contrary to a strong clinical suspicion, a repeat test should be obtained, on the chance that there has been a specimen or laboratory error. Furthermore, there may be patients whose antibody levels are changing, so that
FTA-ABS test results will, on different days, vary between borderline and non-reactive or reactive. The reasons for this variance are as yet unexplained. Also, as in any serological procedure, inherent variations may contribute to apparent fluctuations from day to day and from laboratory to laboratory, especially when reactivity is balanced near the threshold of test sensitivity.

In the light of this study, a useful guide for interpreting an FTA-ABS test result in a patient with aortic valvular insufficiency is that a reastive test suggests, but does not prove, that syphilis is the aetiological factor. A non-reactive FTA-ABS test result makes a luetic aetiology unlikely.

\section{Summary}

The reactivity of the fluorescent treponemal antibody-absorption (FTA-ABS) test was studied in 159 patients with aortic valvular insufficiency. This test was reactive in more patients with clinically diagnosed luetic aortic insufficiency than was the VDRL slide test. However, a reactive FTA-ABS test, a history of syphilis, or both, also occurred in patients with aortic insufficiency presumed to be of non-luetic aetiology. A reactive FTA-ABS test in itself indicates only the likelihood of present or past syphilis; it does not establish that syphilis has caused the aortic insufficiency. A reactive FTA-ABS test in a patient with aortic insufficiency of undetermined aetiology suggests that syphilis should receive further consideration. The diagnosis of luetic aortic insufficiency with a non-reactive FTA-ABS test is suspect and should be re-evaluated. A single FTA-ABS test result not in accord with the clinical impression should be repeated. The FTA-ABS test appears to be a valuable adjunct in the evaluation of patients with aortic valvular insufficiency.

\section{References}

Atwood, W. G., Miller, J. L., Stout, G. W., and Norins, L. C. (1968) f. Amer. med. Ass., 203, 549

Bleich, A., Lewis, J., and Marcus, F. I. (1966, Amer. Heart f., 71, 627

Cohen, P., Stout, G. W., and Ende, N. (1969) Arch. intern. Med., 124, 364

Cole, H. N. (1937) f. Amer. med. Ass., 108, 1861

DeAcon, W. E., Lucas, J. B., and Price, E. V. (1966) Ibid., 198, 624

Hunter, E. F., Norins, L. C., Falcone, V. H., and Stout, G. W. (1968) Bull. Wld Hlth Org., 39, 873

Kampmeier, R. H. (1964) Med. Clin. N. Amer., 48, 667

Olansky, S. (1967). 'Syphilis Rediscovered' 'Disease-aMonth', May, 1967. Year Book Medical Publishers, Chicago, Ill.

RosaHN, P. D. (1955) 'Autopsy Studies in Syphilis. A Monograph'. PHS Publication No. 433. U.S. Government Printing Office, Washington, D.C. 
Slatrin, M. H. (1965) Med. Clin. N. Amer., 49, 823

United States Department of Health, Education and Welfare (1969) 'Manual of Tests for Syphilis'. PHS Publication No. 411. U.S. Government Printing Office, Washington, D.C.

Le test de l'anticorps fluorescent tréponémique absorbé (FTA-ABS) chez les malades atteints d'insuffisance aortique valvulaire

\section{SOMMAIRE}

La réponse au test fluorescent tréponémique absorbé (FTA-ABS) a été étudié chez 159 malades atteints d'insuffisance aortique valvulaire. L'épreuve fut positive chez un plus grand nombre de malades chez lesquels on avait diagnostiqué cliniquement une insuffisance aortique que ne le fut l'épreuve du VDRL sur lame. Cependant, un test FTA-ABS positif, des antécédents de syphilis, ou l'association de l'un et l'autre, sont également rencontrés chez des malades atteints d'insuffisance aortique présumée d'étiologie non syphilitique. Un test FTA-ABS positif, en soi-même, indique seulement la probabilité d'une syphilis présente ou passée; il n'établit pas que la syphilis soit la cause de l'insuffisance aortique. Un test FTA-ABS positif chez un malade présentant une insuffisance aortique d'étiologie indéterminée, demande que la responsabilité de la syphilis soit reprise en considération. Le diagnostic d'insuffisance aortique syphilitique, lorsque le FTA-ABS n'est pas positif, est suspect et doit être reconsidéré. Un test FTA-ABS isolé qui ne concorde pas avec l'impression clinique doit être répété. L'épreuve FTA-ABS apparaît comme un élément d'appoint de valeur dans l'étude de malades atteints d'insuffisance aortique valvulaire. 